\title{
DEGENERATIVE JOINT DISEASE IN A JAMAICAN RURAL POPULATION
}

\author{
BY \\ J. M. BREMNER, J. S. LAWRENCE, AND W. E. MIALL \\ From the Arthritis and Rheumatism Council Field Unit, the MRC Epidemiological Research Unit, Kingston, Jamaica, \\ and the Departments of Rheumatism Research and Occupational Health, the University of Manchester
}

Although degenerative joint disease is known to be very frequent in temperate climates and is responsible for a large proportion of the rheumatic complaints in old people, little information is available on its frequency in tropical and sub-tropical populations. Geographical studies undertaken in Northern Europe and America have indicated regional difference, the radiological changes of osteo-arthrosis being less frequent further north. For example, Blumberg, Bloch, Black, and Dotter (1961) noted a lower frequency in Esquimos in Alaska than in populations in Washington D.C. In Europe less osteo-arthrosis was found in Finland than in the Netherlands (Lawrence, de Graaff, and Laine, 1963). Occupational studies suggest that a warm climate may reduce the complaint rate in persons with degenerative joint disease (Lawrence, 1955, 1961). This paper reports the results of a survey in a rural area of Jamaica, a West Indian island in the sub-tropics.

\section{Population Studied}

A survey of heart disease being carried out by the Medical Research Council's Epidemiological Research Unit in Jamaica provided an opportunity to investigate the prevalence of rheumatic diseases. The area selected for the study was that surrounding the village of Lawrence Tavern, a hilly agricultural district 16 miles inland from Kingston, the capital. The main occupation for the men is the cultivation of mixed crops in small, fertile, but steep plots. Women help with the crops at planting and harvesting seasons, but are otherwise busy with domestic duties at home. The population is mainly of African descent, but many show signs of European, Indian, or Chinese ancestry in their features; poverty is widespread but few people are destitute and the adult population is, in general, well nourished.

Details of the population sampling, and of the techniques used, have been described elsewhere (Fodor,

OSTEO-ARTHROËS II

\begin{tabular}{|c|c|c|c|c|c|c|c|c|c|c|c|c|c|c|c|}
\hline & \multirow{2}{*}{\multicolumn{2}{|c|}{ Population }} & \multirow{3}{*}{$\begin{array}{c}\begin{array}{c}\text { Total } \\
x \text { rayed }\end{array} \\
88 \\
84 \\
88\end{array}$} & \multicolumn{12}{|c|}{ No. of Joints witt } \\
\hline & & & & & & & & & & & & & & & \\
\hline \multirow{4}{*}{ Jamaica } & \multirow[t]{2}{*}{ Males } & $\begin{array}{r}35-44 \\
-54 \\
-64\end{array}$ & & $\begin{array}{l}60 \\
38 \\
21\end{array}$ & $\begin{array}{l}21 \\
23 \\
26\end{array}$ & $\begin{array}{r}6 \\
15 \\
15\end{array}$ & $\begin{array}{l}1 \\
7 \\
9\end{array}$ & $\begin{array}{l}1 \\
9\end{array}$ & 5 & 2 & 1 & & & & $\frac{3}{2}$ \\
\hline & & Total & 260 & 119 & 70 & 36 & 17 & 10 & 5 & 2 & 1 & - & - & - & $\overline{\mathrm{B}}$ \\
\hline & \multirow[t]{2}{*}{ Females } & $\begin{array}{r}35-44 \\
-54 \\
-64\end{array}$ & $\begin{array}{l}93 \\
83 \\
92\end{array}$ & $\begin{array}{l}61 \\
27 \\
16\end{array}$ & $\begin{array}{l}27 \\
29 \\
25\end{array}$ & $\begin{array}{r}4 \\
11 \\
12\end{array}$ & $\begin{array}{r}1 \\
9 \\
15\end{array}$ & $\begin{array}{l}3 \\
9\end{array}$ & 11 & $\frac{1}{2}$ & $\begin{array}{l}1 \\
1\end{array}$ & 1 & 1 & & D్ \\
\hline & & Total & 268 & 104 & 81 & 27 & 25 & 12 & 12 & 3 & 2 & 1 & 1 & - & 势 \\
\hline \multirow{4}{*}{ Wensleydale } & \multirow[t]{2}{*}{ Males } & $\begin{array}{r}35-44 \\
-54 \\
-64\end{array}$ & $\begin{array}{l}84 \\
87 \\
54\end{array}$ & $\begin{array}{l}51 \\
27 \\
11\end{array}$ & $\begin{array}{l}28 \\
35 \\
13\end{array}$ & $\begin{array}{r}2 \\
17 \\
13\end{array}$ & $\begin{array}{l}3 \\
2 \\
5\end{array}$ & $\begin{array}{l}2 \\
6\end{array}$ & $\begin{array}{l}1 \\
3\end{array}$ & $\frac{2}{2}$ & 1 & & 1 & & 䆠 \\
\hline & & Total & 225 & 89 & 76 & 32 & 10 & 8 & 4 & 4 & 1 & - & 1 & - & 14 \\
\hline & \multirow{2}{*}{ Females } & $\begin{array}{r}35-44 \\
-54 \\
-64\end{array}$ & $\begin{array}{l}94 \\
78 \\
68\end{array}$ & $\begin{array}{r}63 \\
35 \\
7\end{array}$ & $\begin{array}{l}25 \\
27 \\
13\end{array}$ & $\begin{array}{r}4 \\
11 \\
12\end{array}$ & $\begin{array}{r}1 \\
4 \\
17\end{array}$ & $\begin{array}{l}1 \\
5\end{array}$ & 5 & $\begin{array}{l}1 \\
7\end{array}$ & 1 & & & 1 & 常 \\
\hline & & Total & 240 & 105 & 65 & 27 & 22 & 6 & 5 & 8 & 1 & - & - & 1 & Ф \\
\hline
\end{tabular}


Miall, Standard, Fejfar, and Stuart, 1964; Lawrence, Bremner, Ball, and Burch, 1966a). 600 adults, 100 of each sex in the three decades from 35-64 years, were selected at random from the total population of 7,500 which had been enumerated by census. 536 subjects (89 per cent. of the sample) cooperated in the study, which included a clinical examination, blood tests, and $\boldsymbol{x}$ rays of hands, feet, cervical and lumbar spine, and knees. Pelvic $x$ rays were obtained for males and for females over age 45. The findings are compared with those of general population surveys carried out in the United Kingdom (Lawrence and Bennett, 1960; Bremner, 1961; Ansell and Lawrence, 1965).

\section{Results}

The prevalence of rheumatic complaints or $x$ ray changes in the Jamaican population was compared with that in the United Kingdom by relating the number of cases observed in Jamaica to that expected from the prevalence in the United Kingdom. Films from the Jamaican survey were mixed with those taken in a survey of an agricultural population in Wensleydale, and were read by an observer who was unaware of the age or race of the individuals. The films were graded 0-4 for osteo-arthrosis and disk degeneration, using the classification recorded in the "Standard Atlas of Radiographs" (C.I.O.M.S., 1963).

\section{Osteo-arthrosis}

The prevalence of osteo-arthrosis found in Jamaica was similar to that in Wensleydale (Table I), but its severity was slightly though not significantly less. A few exceptions were found in the pattern of joint involvement (Fig. 1, overleaf); significantly more osteo-arthrosis in the distal interphalangeal joints of the fingers and in the knees was seen in Jamaicans, for example, and significantly less in the first metatarsophalangeal joints. Jamaican men, but not women, had less osteo-arthrosis in the lumbar spine than those in Wensleydale. Despite the higher prevalence of osteo-arthrosis in the distal interphalangeal joints in Jamaica, idiopathic (i.e. multiple and symmetrically distributed) Heberden's nodes were less frequent than in Wensleydale, occurring in 3 per cent. of males and 8 per cent. of females compared with corresponding prevalences of 7 and 16 per cent. in the United Kingdom. In all joints, except those of the cervical spine, Jamaicans with Grade 3-4 change had milder symptoms than their counterparts in Wensleydale, but the numbers involved were very small (Fig. 2, overleaf).

\section{Disk Degeneration}

The prevalence of radiological evidence of disk degeneration in the lumbar spine was similar in Jamaica and Wensleydale (Table II, overleaf). Disk degeneration (Grade 2-4) was present in the lumbar spine in 159 males in the Jamaican population (65 per cent.), a rate closely similar to the 154 expected on the basis of Wensleydale males; age relationship was the same in both races. Its prevalence in Jamaican females was lower than in males, 56 per cent. having Grade 2-4 change, but slightly higher than the 45 per cent. expected on the basis of Wensleydale females. Though the proportion of both males and females with evidence of some disk degeneration in

MÁICA AND WENSLEYDALE

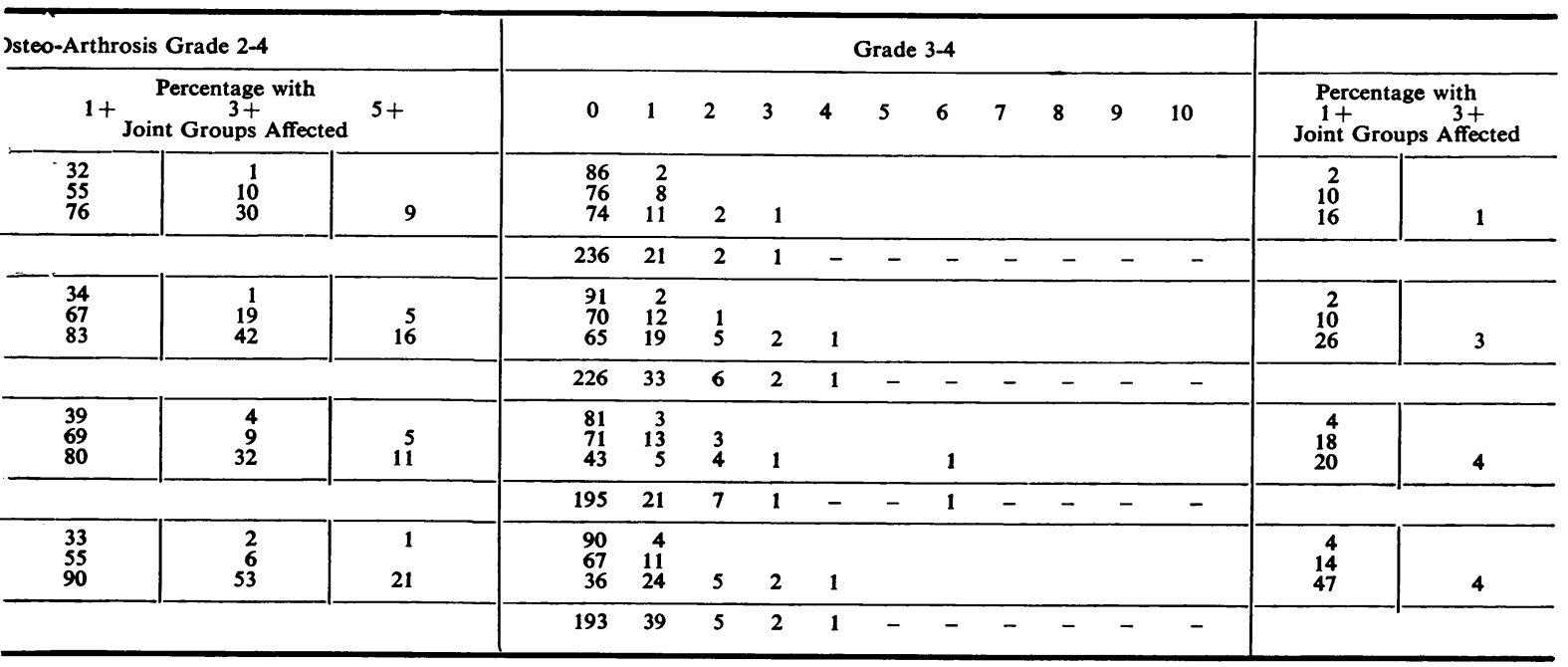




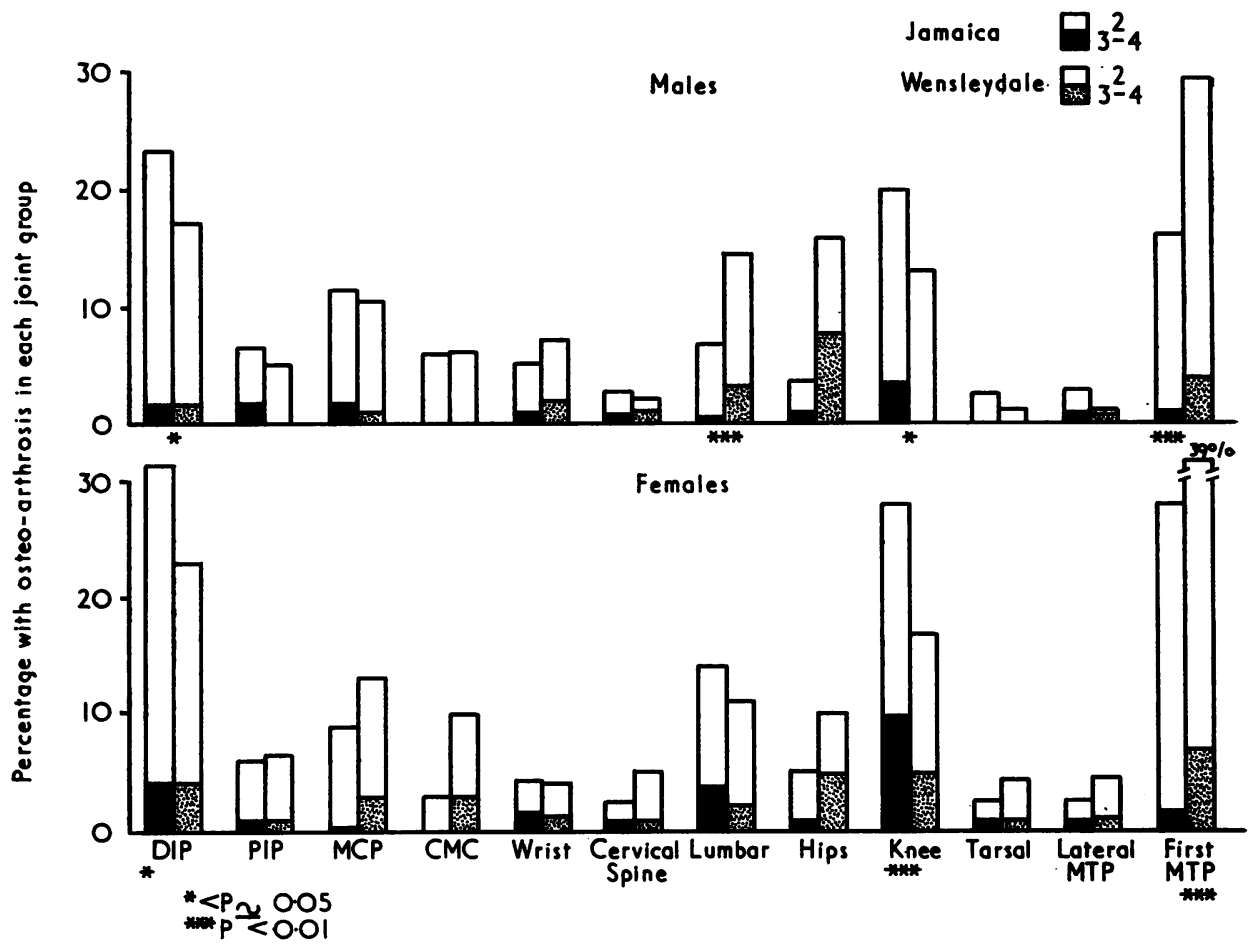

Fig. 1.-Joint pattern of osteo-arthrosis in Jamaica and Wensleydale, by sex.

TABLE II

RADIOLOGICAL EVIDENCE OF DISK DEGENERATION IN THE JAMAICAN POPULATION

\begin{tabular}{|c|c|c|c|c|c|c|c|c|c|c|c|c|}
\hline \multirow{4}{*}{$\begin{array}{c}\text { Spine } \\
\text { Lumbar }\end{array}$} & \multirow{4}{*}{\begin{tabular}{l}
\multicolumn{1}{c}{ Sex } \\
\\
$\begin{array}{l}\text { Male } \\
\text { Female }\end{array}$
\end{tabular}} & \multirow{4}{*}{$\begin{array}{c}\begin{array}{c}\text { Total } \\
x \text { rayed }\end{array} \\
246 \\
255\end{array}$} & \multicolumn{8}{|c|}{ Grade of Disk Degeneration } & \multirow{2}{*}{\multicolumn{2}{|c|}{$\begin{array}{c}\text { Number with More } \\
\text { than Three Disks } \\
\text { Affected }\end{array}$}} \\
\hline & & & \multicolumn{4}{|c|}{$2-4$} & \multicolumn{4}{|c|}{$3-4$} & & \\
\hline & & & \multicolumn{2}{|c|}{$\begin{array}{l}\text { Observed } \\
\text { No. } \quad \text { Per cent. }\end{array}$} & \multicolumn{2}{|c|}{$\begin{array}{c}\text { Expected } \\
\text { No. Per cent. }\end{array}$} & \multicolumn{2}{|c|}{$\begin{array}{l}\text { Observed } \\
\text { No. Per cent. }\end{array}$} & \multicolumn{2}{|c|}{$\begin{array}{l}\text { Expected } \\
\text { No. Per cent. }\end{array}$} & $\overline{\text { Observed }}$ & Expected \\
\hline & & & $\begin{array}{l}159 \\
143\end{array}$ & $\begin{array}{l}65 \\
56\end{array}$ & $\begin{array}{l}154 \\
116\end{array}$ & $\begin{array}{l}63 \\
45\end{array}$ & $\begin{array}{l}27 \\
16\end{array}$ & $\begin{array}{r}11 \\
6\end{array}$ & $\begin{array}{l}23 \\
21\end{array}$ & $\begin{array}{l}9 \\
8\end{array}$ & $\begin{array}{l}56 \ddagger \\
48 \ddagger\end{array}$ & $\begin{array}{l}22 \cdot 2 \\
12 \cdot 9\end{array}$ \\
\hline Cervical & $\begin{array}{l}\text { Male } \\
\text { Female }\end{array}$ & $\begin{array}{l}258 \\
268\end{array}$ & $\begin{array}{l}165 \\
177\end{array}$ & $\begin{array}{l}64 \\
66\end{array}$ & $\begin{array}{r}97 \\
110\end{array}$ & $\begin{array}{l}38 \\
41\end{array}$ & $\begin{array}{l}75 \\
64\end{array}$ & $\begin{array}{l}29 \\
24\end{array}$ & $\begin{array}{l}39 \\
40\end{array}$ & $\begin{array}{l}15 \ddagger \\
15 \ddagger\end{array}$ & $\begin{array}{l}43 \ddagger \\
36 \ddagger\end{array}$ & $\begin{array}{l}1 \cdot 6 \\
7 \cdot 3\end{array}$ \\
\hline
\end{tabular}

$+\cdot 01>\mathrm{P}>\cdot 05 \quad \mp \mathrm{P}<\cdot 01$

the lumbar spine was similar to that found in Wensleydale, a highly significant excess of Jamaicans showed extensive degenerative changes involving more than three disks. Comparison with the Wensleydale populations shows, however, that for Jamaican men each grade of disk degeneration was associated with less back-hip-sciatic pain, and there was also less loss of work (Fig. 3, opposite).

Cervical disk degeneration had a significantly higher prevalence in both sexes in Jamaica than in Wensleydale (Table II) and, as was found in the lumbar spine, many more Jamaicans than would be expected had more than three disks affected. The fifth cervical disk was most commonly affected in both surveys, but the fourth and sixth were also frequently involved. Despite their more severe and more widespread cervical lesions, Jamaicans complained less of neck-shoulder-brachial pain than did 


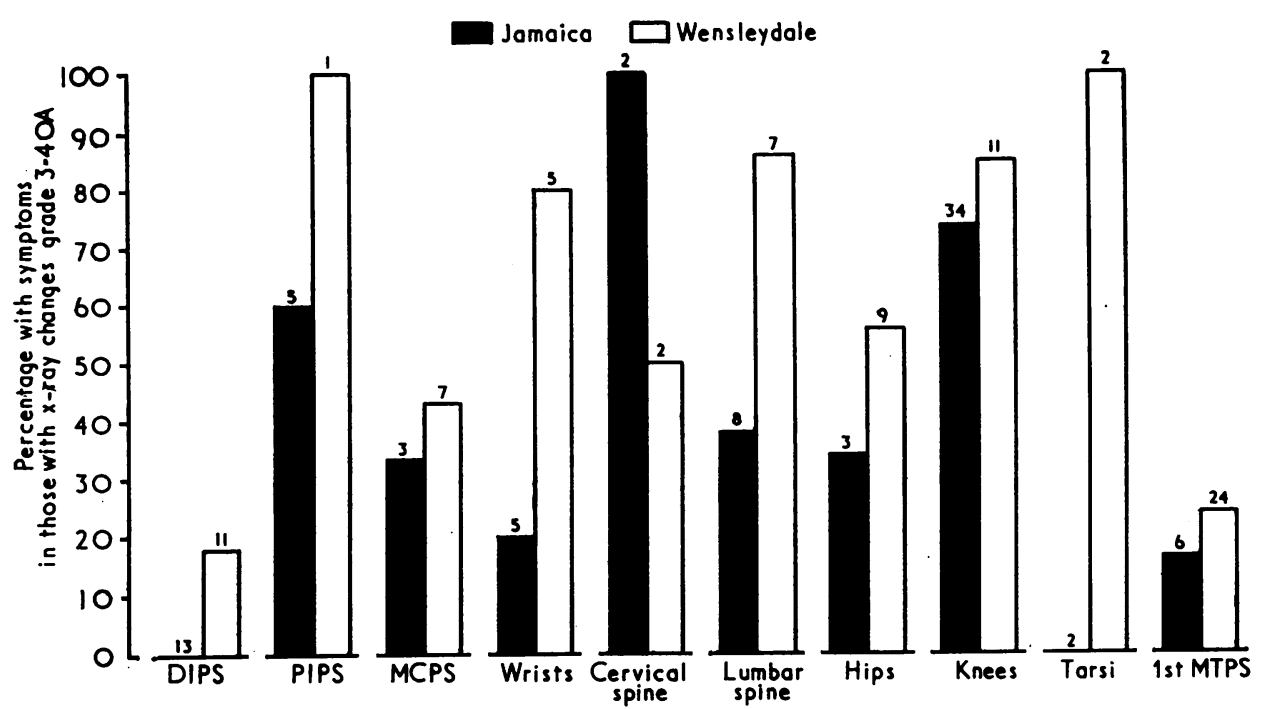

Note Figures above columns indicate number with grade 3-4 osteo-orthrosis

Fig. 2.-Relationship of symptoms to $x$-ray changes of osteo-arthrosis in Jamaica and Wensleydale.

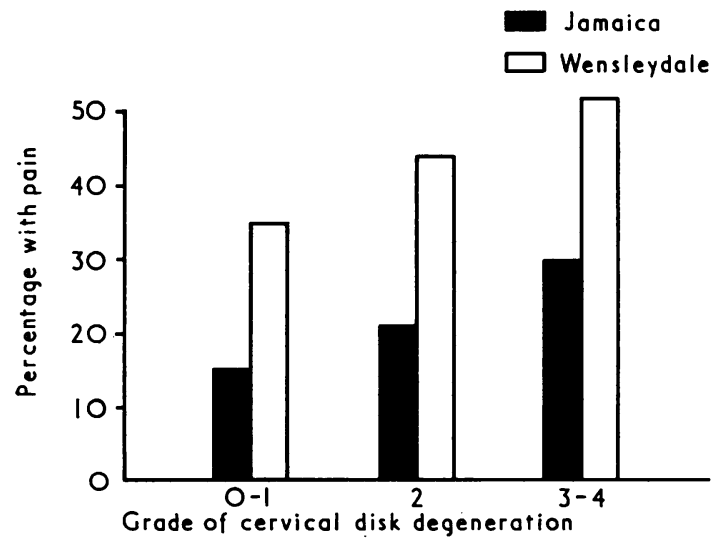

Fig. 3.-Lumbar and sciatic pain related to lumbar disk degeneration in Jamaica and Wensleydale.

people in Wensleydale. Pain at the time of the survey was less prevalent and previous loss of work from neck-shoulder-brachial pain was also less (Table III, overleaf). For each grade of cervical disk degeneration, symptoms were less prevalent in Jamaica (Fig. 4).

\section{Prevalence of Rheumatic Complaints}

Of the 263 males who were questioned about rheumatic complaints, 167 stated that they had experienced pain in the joints or muscles at some time compared with 190 expected from the results 
TABLE III

DISABILITY FROM NECK-SHOULDER-BRACHIAL PAIN IN JAMAICA AND WENSLEYDALE

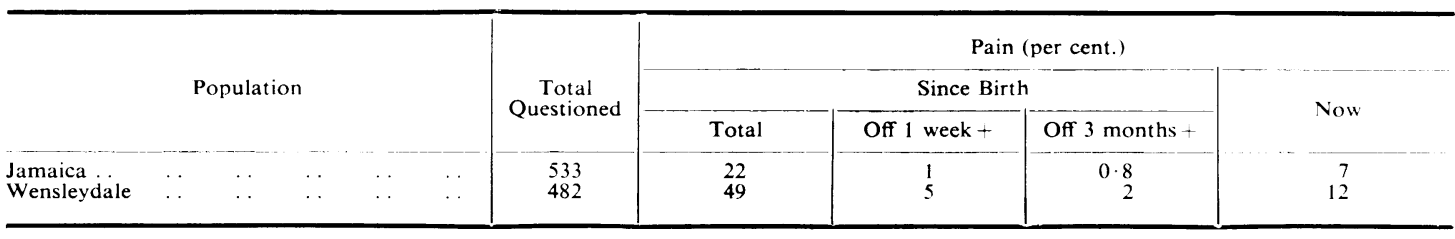

Correction for age differences is made by using the unweighted mean of the three decades

TABLE IV

RHEUMATIC COMPLAINTS IN THE JAMAICAN POPULATION

\begin{tabular}{|c|c|c|c|c|c|c|c|c|c|c|c|}
\hline \multirow{4}{*}{ Sex } & \multirow{4}{*}{$\begin{array}{c}\text { Total } \\
\text { Questioned }\end{array}$} & \multirow{4}{*}{ Complaints } & \multirow{2}{*}{\multicolumn{2}{|c|}{$\begin{array}{c}\text { Total } \\
\text { with Symptoms }\end{array}$}} & \multicolumn{7}{|c|}{ Incapacity from Rheumatic Complaints } \\
\hline & & & & & \multicolumn{3}{|c|}{ Any time } & \multicolumn{4}{|c|}{ Now } \\
\hline & & & Now & Any time & 1 week $t$ & \multicolumn{2}{|c|}{3 months +} & \multicolumn{2}{|c|}{1 week +} & \multicolumn{2}{|c|}{3 months +} \\
\hline & & & Obs. Exp. & Obs. Exp. & Act. Exp. & Act. & Exp. & Act. & Exp. & Act. & Exp \\
\hline \multirow{2}{*}{ Male } & \multirow{2}{*}{263} & No. & $74 \quad 84$ & $167 \quad 190$ & 75 & 13 & 28 & 8 & 5 & 7 & 3 \\
\hline & & Per cent. & $28 \mathrm{NS} 32$ & $63+72$ & $12+28$ & $5+$ & 11 & 3 & 2 & 3 & 1 \\
\hline \multirow{2}{*}{ Female } & \multirow{2}{*}{272} & No. & $105 \quad 119$ & $194 \quad 211$ & 19 & 8 & 22 & 3 & 4 & 1 & 3 \\
\hline & & Per cent. & $39 \mathrm{NS} 44$ & $72 * \quad 78$ & $7+29$ & $3+$ & & 1 & 1 & 0.4 & 1 \\
\hline
\end{tabular}

region and the knees, but all were much less commonly involved than in Wensleydale (Fig. 5). Pain in multiple undefined sites was more common in Jamaica and probably reflects the relatively high prevalence of inflammatory polyarthritis in this population (Lawrence and others, 1966a).

\section{Discussion}

The differences between the frequency of rheumatic complaints in Jamaica and Wensleydale were confined to the past history of symptoms, suggesting that difficulties of communication in the Jamaican

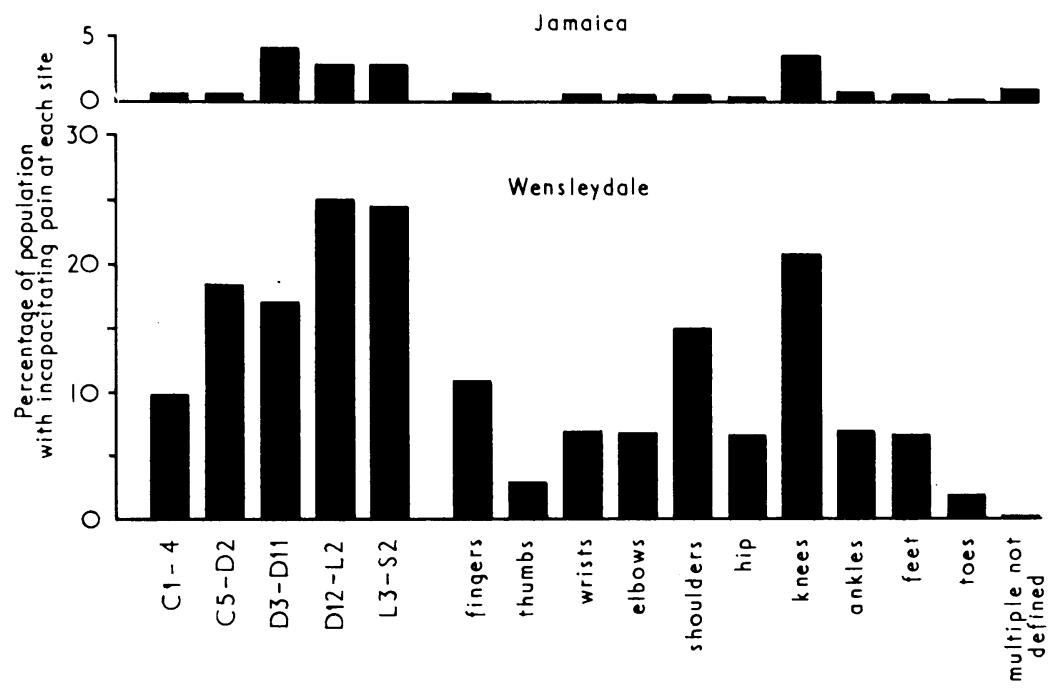

Fig. 5.-Incapacitating pain in joints in Jamaica and Wensleydale. 
survey could have been responsible. Both observers and respondents may have found each others' dialects strange, so that it was not always certain that question or answer was fully understood. Another difference was that in Wensleydale the $x$-ray survey was preceded by a symptoms survey so that each respondent was asked about rheumatism twice; although only the answers on the second occasion were used, memory may have been helped by the previous questionnaire. The majority of Jamaican males were self-employed cultivators, and though it is possible that rheumatic complaints causing a few days loss of work might have been more readily forgotten, this would be unlikely to have occurred where incapacity had been prolonged.

The greater prevalence and severity of cervical disk degeneration in Jamaicans may be due to the practice of carrying heavy loads on the head. Though cervical disk degeneration is common, it is not thought to be a cause of the unexplained neuropathy described from Jamaica by Cruickshank and his colleagues (Cruickshank, Montgomery, and Spillane, 1956; Montgomery, Cruickshank, Robertson, and McMenemey, 1964).

The greater prevalence of osteo-arthrosis of the knees in Jamaicans might be explained by the rough footpaths along which they must walk. Their lower frequency of osteo-arthrosis in the first metatarsophalangeal joints may be related to their habit of walking without shoes. The greater involvement of the distal-interphalangeal joints of the fingers is difficult to explain. These joints are characteristically affected in the genetically determined nodal form of generalized osteo-arthrosis, but few Heberden's nodes were seen. Negroes may be relatively immune to the nodal type of osteoarthrosis; Stecher (1940) in the U.S.A. found a lower prevalence among Negroes than among whites.

The lower frequency of symptoms and resultant incapacity in Jamaicans suggests either an ethnic difference in pain threshold or the presence of other factors which cause Jamaicans with the same sever ity of rheumatic disease to suffer less pain. We have no evidence concerning pain thresholds in the two populations. Recent surveys in the United Kingdom have shown that occupational and environmental factors appear to influence rheumatic complaints. Radiant heat and temperature may be important. Foundry workers, for example, have been shown to have more disk degeneration in the lumbar spine than the rest of the population, but fewer symptoms in relation to the degree of $x$-ray change (Lawrence, Molyneux, and DingwallFordyce, 1966b). Miners working in warm, dry seams had fewer complaints than those in cold, wet seams (Lawrence, 1955).

It is possible that the higher temperature and greater amount of sunshine together with light-weight clothing leading to a high exposure to radiant heat, may explain the lower frequency of complaints in Jamaica despite the fact that degenerative joint disease is equally common.

\section{Summary}

The prevalence of degenerative joint disease has been measured in a random sample of adults aged 35-64 years living in a rural area in Jamaica and compared with that found in similar surveys in the United Kingdom.

Radiological evidence of osteo-arthrosis in general showed the same prevalence in the two races, with the exception of certain joints which showed significant differences. Lumbar disk degeneration was also found to have a similar prevalence, though the involvement of multiple disks was significantly more common in Jamaica. Cervical disk degeneration was both more common and more severe in Jamaica.

Symptoms in Jamaica were less frequent in relation to all sites of osteo-arthrosis except the cervical spine, and Jamaicans seemed to have fewer symptoms and less incapacity than Englishmen with the same degree of disk degeneration.

We should like to thank the people of Lawrence Tavern, Jamaica, who cooperated in this study, and our colleagues of the MRC Epidemiological Research Unit and the Arthritis and Rheumatism Council Field Unit who helped with the field work.

\section{REFERENCES}

Ansell, B. M., and Lawrence, J. S. (1965). Ann. rheum. Dis., 25, 67 (Fluoridation and the rheumatic diseases. A comparison of rheumatism in Watford and Leigh).

Blumberg, B. S., Bloch, K. J., Black, R. L., and Dotter, C. (1961). Arthr. and Rheum., 4, 325 (A study of the prevalence of arthritis in Alaskan Eskimos). 
Bremner, J. M. (1961). Ann. rheum. Dis., 20, 149 (Rheumatic complaints in a rural population).

C.I.O.M.S. (1963). "The Epidemiology of Chronic Rheumatism", vol. 2, "Atlas of Standard Radiographs of Arthritis". Blackwell, Oxford.

Cruickshank, E. K., Montgomery, R. D., and Spillane, J. D. (1961). Wld Neurol., 2, 199 (Obscure neurologic disorders in Jamaica).

Fodor, J., Miall, W. E., Standard, K. L., Fejfar, Z., and Stuart, K. L. (1964). Bull. Wld Hlth Org., 31, 321 (Myocardial disease in a rural population in Jamaica).

Lawrence, J. S. (1955). Brit. J. industr. Med., 12, 249 (Rheumatism in coal miners. Part III: Occupational factors).

- (1961). Ibid., 18, 270 (Rheumatism in cotton operatives). and Bennett, P. H. (1960). Ann. rheum. Dis., 19, 20 (Benign polyarthritis).

—, Bremner, J. M., Ball, J., and Burch, T. A. (1966a). Ibid., 25, 59 (Rheumatoid arthritis in a sub-tropical population).

—, de Graaff, R., and Laine, V. A. I. (1963). In "Epidemiology of Chronic Rheumatism", ed. J. H. Kellgren, vol. 1, p. 98 (Degenerative joint disease in random samples and occupational groups). Blackwell, Oxford.

- Molyneux, M. K., and Dingwall-Fordyce, I. (1966b). Brit. J. industr. Med., 23, 42 (Rheumatism in foundry workers).

Montgomery, R. D., Cruickshank, E. K., Robertson, W. B., and McMenemey, W. H. (1964). Brain, 87, 425 (Clinical and pathological observations on Jamaican neuropathy).

Stecher, R. M. (1940). New Engl. J. Med., 222, 300 (Heberden's nodes: the incidence of hypertrophic arthritis of the fingers).

Atteinte dégénérative articulaire dans une population rurale de la Jamaique

\section{RÉSUMÉ}

On a determiné la fréquence de l'atteinte dégénérative articulaire dans un groupe d'adultes âgés de 35 à 64 ans, pris au hasard dans une zone rurale de la Jamaïque et on l'a comparée à celle établie lors d'enquêtes similaires au Royaume Uni.

En général, les signes radiologiques d'ostéoarthrose étaient aussi fréquents dans les deux races, exception faite pour certaines articulations qui montraient des différences significatives. La fréquence était analogue pour l'atteinte dégénérative discale lombaire, bien que celle de plusieurs disques ait été plus grande à la Jamaïque. L'atteinte cervicale était à la fois plus commune et plus grave à la Jamaïque.

A la Jamaïque les signes fonctionnels étaient moins fréquents en ce qui concerne toutes les localisations de l'ostéoarthrose sauf la colonne cervicale et, avec le même degré de dégénérescence discale, les manifestations fonctionnelles et l'invalidité semblaient moins importantes dans la population jamaicaine que dans la population anglaise.
Enfermedad articular degenerativa en una población rural de Jamaica

\section{SUMARIO}

Se determinó la frecuencia de la enfermedad articular degerativa en un grupo de adultos de 35 a 64 años de edad, escogidos al azar en una zona rural de Jamaica y se comparo esta frecuencia con la encontrada anteriormente en el curso de investigaciones similares en Gran Bretaña.

En general, los signos radiológicos de osteoartrosis se vieron con igual frecuencia en ambas razas, con la excepción de ciertas articulaciones que acusaron diferencias significativas. Los discos lumbares se vieron afectados con la misma frecuencia, pero la afección multiple de estos discos fué significativamente más común en Jamaica. La degeración de los discos cervicales fué más común y más en Jamaica.

Las manifestaciones subjetivas en Jamaica fueron menos frecuentes respecto a todas las localizaciones de la osteoartrosis con la excepción del cuello. En general los jamaicanos aquejaron menos síntomas y sufrieron menos incapacidad que los ingleses con un grado similar de degeneración discal. 